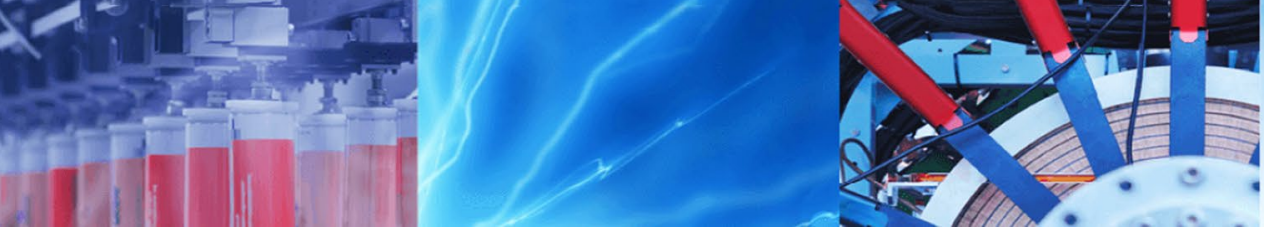

Review Paper

\title{
Addition of ceramics materials to improve the corrosion resistance of alumina refractories
}

\author{
A. Valenzuela-Gutiérrez ${ }^{1} \cdot J^{\text {. López-Cuevas }}{ }^{2} \cdot$ A. González-Ángeles $^{1}$ [D $\cdot$ Nun Pilalua-Díaz $^{3}$
}

(c) Springer Nature Switzerland AG 2019

\begin{abstract}
This review shows that adding ceramic materials such as $\mathrm{ZrO}_{2}, \mathrm{ZrSiO}_{4}, \mathrm{TiO}_{2}, \mathrm{SiO}_{2}, \mathrm{Cr}_{2} \mathrm{O}_{3}$, etc., to abase alumina refractory clay, improves the corrosion resistance under the presence of acid $\left(\mathrm{H}_{2} \mathrm{SO}_{4}, \mathrm{HCl}, \mathrm{HNO}_{3}\right.$, etc) and/or alkaline $(\mathrm{NaOH}, \mathrm{KOH}$, $\mathrm{Na}_{2} \mathrm{O}, \mathrm{Ca}(\mathrm{OH})_{2}$, etc) solutions. Characterization techniques, such as SEM, XRD, ICP-MS analysis, and weight loss show individual or correlated properties between apparent porosity, bulk density, mass loss, total number of eluted ions from alumina refractories, and the degree of corrosion resistance obtained by sintering. Static and dynamic (ASTM C-874) slag cup tests are performed by immersion or exposure to a continuous flow stream in acid and/or alkaline solutions. Results show that adding $81.6 \mathrm{~mol} \% \mathrm{Cr}_{2} \mathrm{O}_{3}, 4$ mol\% $\mathrm{TiO}_{2}$ to the $\mathrm{Al}_{2} \mathrm{O}_{3}$ base reduces corrosion damage depth by $\mathrm{SiO}_{2}-\mathrm{CaO}_{2}-\mathrm{Al}_{2} \mathrm{O}_{3}$ molten oxide. Sintered mullite matrix increases its corrosion resistance against alkaline vapors by adding $16 \%$ of $\mathrm{ZrSiO}_{4}$. $\mathrm{SiO}_{2}-\mathrm{Al}_{2} \mathrm{O}_{3}$ refractory ceramics with mixtures of $67-23,56-38,25-71 \%$, respectively, have $98 \%$ resistance against acid solutions. However, their resistance to alkaline solutions is $58 \%$ with $23 \%$ alumina and rises up to $88 \%$ with $71 \%$ of alumina. It is concluded that higher content of corundum $\left(\mathrm{a}-\mathrm{Al}_{2} \mathrm{O}_{3}\right)$ and mullite phases on refractory ceramic improves its resistance to acid and alkaline solutions and that the attack of degrading solution is preferential over impurities in the phases present near the grain boundaries.
\end{abstract}

Keywords Refractory ceramics $\cdot$ Acid and alkaline resistance $\cdot$ Mullite $\cdot$ Corundum

\section{Introduction}

The industry (energy or petrochemical) has the need to incinerate corrosive gases product of waste, which cannot be discharged to the atmosphere for ecological reasons. One of the major challenges of the industry is to increase the corrosion resistance of refractory materials and to improve the durability of combustion chambers in power plants used for waste incineration.

By increasing corrosion resistance of refractory materials, the durability of combustion chambers in energy plants used for waste incineration is improved. Ceramic materials such as $\mathrm{Al}_{2} \mathrm{O}_{3}$ have been used as refractories in combustion chambers, despite the severe corrosion that occurs by fusing gases. $\mathrm{Al}_{2} \mathrm{O}_{3}$ is always the first option as a refractory because it is less expensive, easy to handle and produce. Latest developments in non-oxide refractory ceramics are $\mathrm{SiC}$ y MgO-C (magnesia-carbon refractory), but these materials cannot be used in highly oxidizing atmospheres, including combustion chambers, due to poor thermal shock resistance of $\mathrm{MgO}$. Although $\mathrm{Cr}_{2} \mathrm{O}_{3}$ may be the first candidate as a compound for $\mathrm{Al}_{2} \mathrm{O}_{3}$, diffusion rate of the $\mathrm{Cr}$ ion is smaller than any other metal ions; however, pure $\mathrm{Cr}_{2} \mathrm{O}_{3}$ reacts with the basicity of the slag, expelling toxic $\mathrm{Cr}^{6+}$ into the sintered body or slag [1].

A. González-Ángeles, gangelesa@uabc.edu.mx | ${ }^{1}$ Facultad de Ingeniería, Universidad Autónoma de Baja California, Blvd. Benito Juárez S/N, 21280 Mexicali, B.C., Mexico. ${ }^{2}$ CINVESTAV-IPN, Unidad Saltillo, Calle Industria Metalúrgica No. 1062, Parque Industrial Saltillo - Ramos Arizpe, CP 25900 Ramos Arizpe, Coahuila, Mexico. ${ }^{3}$ Departamento de Ingeniería Industrial, Universidad de Sonora, Blvd. Luis Encinas y Rosales S/N Col. Centro, CP 83000 Hermosillo Sonora, Mexico. 
Refractory materials in operation are subjected to three types of loads: thermal, mechanical, and chemical. Chemical resistance of ceramics is defined as the ability to withstand destructive action in an aggressive environment. This resistance depends on the properties of the aggressive medium, chemical composition and structure of the ceramic, and the conditions of the corrosion process, especially the point of contact between the ceramic and the aggressive medium [2]. The life cycle of a refractory material is usually determined by the degree of corrosion it can withstand [3]. Corrosion may occur by a gas (inert or chemically active) or by a liquid (acid solutions, bases, salts, molten salts, glass, slag, metals, fresh or sea water, etc) [2].

A lot of scientific papers have been published on corrosion in alumina under several conditions, where corrosion behavior of highly pure alumina at room temperature for periods of 10 days, in a solution of $\mathrm{H}_{2} \mathrm{SO}_{4}$ at different concentrations ( $2 \mathrm{wt} \%, 10 \mathrm{wt} \%$ and $20 \mathrm{wt} \%$ ), shows that impurities ( $\mathrm{MgO}, \mathrm{CaO}, \mathrm{SiO}, \mathrm{Na}_{2} \mathrm{O}$, etc.) present in the grain boundaries are the first cause of corrosion in high-purity alumina ceramics $[4,5]$.

Multiple processes contribute to the corrosion of refractory materials, but these processes are always based on the physicochemical properties of the corrosive agent and on the intrinsic properties of the refractory materials, such interconnected porosity [6] and the presence of mullite phase $3 \mathrm{Al}_{2} \mathrm{O}_{3} 2 \mathrm{SiO}_{2}$ [7]. A high interconnected porosity allows the access of external agents and increases the surface of reaction, which favors material interaction and corrosion. Also, refractories are multiphase materials that enable preferential or selective attack [6].

For example, mullite phase [7] is the only stable crystalline phase in the aluminosilicate system under normal atmospheric pressure. The high levels of functional properties of aluminosilicate ceramics depend on the general content of mullite on its structural and morphological states [7], including resistance to acid and alkaline solutions [5]. Therefore, the industrial methods for producing aluminosilicate ceramics are based on the highest formations of $\mathrm{mul}$ lite quantity. This is achieved by using the refractory clays with high amount of $\mathrm{SiO}_{2}$ and alumina $\mathrm{Al}_{2} \mathrm{O}_{3}$ and $\mathrm{SiO}_{2}$ [7].

\section{Materials and methods}

Eight of the most abundant elements in Earth are presented in Table 1. Silicon is never found in its elemental form, but in form of silicate minerals, and their structures depend on the composition and formation conditions of the place where they are found. They can be contained in relatively pure mineral deposits or in deposits made up of one or more mineral species [8].

It is very common for alumino silicates to be referred with the term "clay," but dozens of minerals fall under the classification of clay, and a single clay deposit may contain a variety of individual clay minerals along with impurities. Therefore, clay minerals are classified as phyllo silicates, due to their layered structure. The most common clay mineral is kaolinite $\mathrm{Al}_{2} \mathrm{Si}_{2} \mathrm{O}_{5}(\mathrm{OH})_{4}$, although others such as montmorillonite $(\mathrm{NaCa})_{0.33}(\mathrm{Al}, \mathrm{Mg})_{2} \mathrm{Si}_{4} \mathrm{O}_{10}$ $(\mathrm{OH})_{2} \mathrm{nH}_{2} \mathrm{O}$, and vermiculite $\left[\left(\mathrm{Si}_{3.04} \mathrm{Al}_{0.92} \mathrm{Ti}_{0.04}\right)\right.$ $\left.\left(\mathrm{Al}_{0.11} \mathrm{Fe}_{0.35}^{3+} \mathrm{Fe}_{0.07}^{2+} \mathrm{Mg}_{2.41} \mathrm{Mn}_{0.003}\right) \mathrm{O}_{10}(\mathrm{OH})_{2}\right] \mathrm{Ca}_{0.21} \mathrm{~K}_{0.05} \mathrm{Na}_{0.10}$ are also abundant [8].

The type and proportion of clay minerals in individual sediments are related to sediments of source rocks, weather conditions, and transport mechanisms that occur in the material according to Biscaye [9], Liangbiao and Liu [10]. Also in the study by Kurkura Kabeto [11], sediments of the clay show the presence of kaolinite as main mineral, over a base of kaolin and other minerals associated with clay. These can be divided in to four types: kaolinite, microcline $\mathrm{KAISi}_{3} \mathrm{O}_{8}$, kaolinite $3 \mathrm{Al}_{2} \mathrm{O}_{3}$ $2 \mathrm{SiO}_{2} 2 \mathrm{H}_{2} \mathrm{O}$, muscovite $\mathrm{KAl}_{2} \mathrm{Si}_{3} \mathrm{AlO}_{10}(\mathrm{OH})_{2}$-microcline $\mathrm{KAISi}_{3} \mathrm{O}_{8}$-kaolinite $3 \mathrm{Al}_{2} \mathrm{O}_{3} 2 \mathrm{SiO}_{2} 2 \mathrm{H}_{2} \mathrm{O}$. However, in their study, clays show other associated minerals such as $\mathrm{SiO}_{2}$ quartz, vermiculite $\mathrm{Mg}_{0,7}(\mathrm{Mg}, \mathrm{Fe}, \mathrm{Al})_{6}(\mathrm{Si}, \mathrm{Al})_{8} \mathrm{O}_{20}(\mathrm{OH})_{4} \cdot 8 \mathrm{H}_{2} \mathrm{O}$, albite $\mathrm{NaSi}_{3} \mathrm{AlO}_{8}$, calcite $\mathrm{CaCO}_{3}$ and calcite magnesia in less quantity [11].

Clay minerals from different regions are added in certain compositions to formulate corrosion resistant alumina refractories. Mineral extraction is carried out in open sky. It is subsequently cracked to homogenization (ASTM C-702) and dried at $110^{\circ} \mathrm{C}$ for up to 24 h. $[12,13]$. Samples are reduced to microns $(40-74 \mu \mathrm{m})$, using in some cases mixtures of different grain sizes $[3,7,14]$ and using ball mills to produce superficial and structural changes to the solid material [15]. The ball and load ratio for ball mills varies between 10,15 and $20-1$, respectively, with rotation speeds between 250 and $480 \mathrm{rpm}[16,17]$. They were sieved to obtain homogeneous particle size (ASTM C-136). Samples that are subjected to corrosion tests are formed into cylinders [3,13], rectangles [14] or squares, mostly with variable dimensions by cold isostatic compaction using a hydraulic press at 10.12, 22, 40, 50, 75 and even $150 \mathrm{Mpa}$ [3].
Table 1 Chemical composition of crust of Earth [8]

\section{SN Applied Sciences

\begin{tabular}{llllllllll}
\hline Element & $\mathrm{O}$ & $\mathrm{Si}$ & $\mathrm{Al}$ & $\mathrm{Fe}$ & $\mathrm{Ca}$ & $\mathrm{Na}$ & $\mathrm{K}$ & $\mathrm{Mg}$ & Others \\
\hline Percent by weight & 50 & 26 & 7.5 & 4.7 & 3.4 & 2.6 & 2.4 & 1.9 & 1.5 \\
\hline
\end{tabular}


They are sintered an oven at heating rates of $2-10^{\circ} \mathrm{C} /$ $\min$ [7] and temperatures of $1600-1700{ }^{\circ} \mathrm{C}$. The soaking times are ranging from a few hours up to few days, depending on the composition of the mixture and phases to be obtained [3]. The cooling is carried out inside the oven off. Static [18] or dynamic [13,19] testing for corrosion resistance is made by chemical reaction, simulating conditions of a real application, at certain temperature, atmospheric pressure or vacuum, and with acid or alkaline substances, through methods such as cup slag test, drip slag test (ASTM C-768), gradient slag test, rotary slag test (ASTM C-874) and dip and spin test.

\section{Result and discussion}

A diffusion of ions (atoms) is common between a ceramic material and the aggressive medium. But it is not necessary to consider this interaction as destruction and subsequent loss of ceramic material. In ceramic corrosion, there are two main types of chemical resistance, which are acid and alkaline. Table 2 shows chemical resistance for alumina oxide, through mass loss under different reactive media [2].

Booklet of the Friedrichsfeld Company (Germany) reported the mass loss (Table 3 ) to measure chemical resistance of ceramics with 96.0 and $99.5 \%$ of $\mathrm{Al}_{2} \mathrm{O}_{3}$ subjected to several acid and alkaline media [2].

In a ceramic mixture of silica and alumina, corrosion resistance is higher under acidic than alkaline media, and mass loss under acidic is lower than alkaline medium, Table 4.

Long Huang, Luo and $\mathrm{Li}$ [20] studied $\mathrm{Al}_{2} \mathrm{O}_{3}$ alumina ceramics under acid and alkaline corrosion, sieved, uniaxially packed at $200 \mathrm{MPa}$ and sintered at $1450^{\circ} \mathrm{C}$ for $2 \mathrm{~h}$. Then, he calculated mass loss in solutions of $50 \mathrm{ml} \mathrm{HCl}$ and $\mathrm{NaOH}$. Huang et al. determined through the sample

Table 2 Chemical resistance of aluminum oxide ceramics in different acids and alkalis [2]

\begin{tabular}{llll}
\hline Reactant & $\begin{array}{l}\text { Mass content } \\
\text { wt\% }\end{array}$ & $\begin{array}{l}\text { Temperature } \\
\text { treatment }{ }^{\circ} \mathrm{C}\end{array}$ & $\begin{array}{l}\text { Weight loss, mg } \\
\left(\mathrm{cm}^{2} \text { year }\right) \\
\text { Densely sintered } \\
\mathrm{Al}_{2} \mathrm{O}_{3}\left(99 \text { wt } \% \mathrm{Al}_{2} \mathrm{O}_{3}\right)\end{array}$ \\
\hline $\mathrm{H}_{2} \mathrm{SO}_{4}$ & 98 & 100 & 65.0 \\
$\mathrm{HNO}_{3}$ & 70 & 100 & 7.0 \\
$\mathrm{H}_{3} \mathrm{PO}_{4}$ & 85 & 100 & $<1000$ \\
$\mathrm{HCl}$ & 25 & 70 & 72.0 \\
$\mathrm{HF}$ & 53 & 25 & 20.0 \\
$\mathrm{HF}+\mathrm{HNO}_{3}$ & $10+57$ & 25 & 16.0 \\
$\mathrm{NaOH}$ & 50 & 100 & 75.0 \\
$\mathrm{KOH}$ & 45 & 100 & 6.0 \\
\hline
\end{tabular}

Table 3 Chemical resistance of corundum ceramics in different acids and alkalis [2]

\begin{tabular}{lccll}
\hline Reactant & $\begin{array}{l}\text { Mass } \\
\text { content } \\
\%\end{array}$ & $\begin{array}{l}\text { Temperature } \\
\text { treatment }{ }^{\circ} \mathrm{C}\end{array}$ & $\begin{array}{l}\text { Corrosion, mm/year, of } \\
\text { corundum ceramics, less } \\
\text { than }\end{array}$ \\
\cline { 3 - 5 } & & & $\begin{array}{l}\text { Frialit F-96 } \\
(96.0 \%\end{array}$ & $\begin{array}{l}\text { Frialit F-99.7 } \\
\left(99.5 \% \mathrm{Al}_{2} \mathrm{O}_{3}\right)\end{array}$ \\
& & & $\left.\mathrm{Al}_{2} \mathrm{O}_{3}\right)$ & \\
\hline $\mathrm{H}_{2} \mathrm{SO}_{4}$ & 97 & 105 & 0.110 & 0.120 \\
$\mathrm{HNO}_{3}$ & 65 & 105 & 0.030 & 0.040 \\
$\mathrm{H}_{3} \mathrm{PO}_{4}$ & 105 & 105 & 0.090 & 0.095 \\
$\mathrm{HCl}$ & 35 & 105 & 0.018 & 0.020 \\
$\mathrm{HF}$ & 40 & 20 & 0.450 & 0.100 \\
$\mathrm{C}_{6} \mathrm{H}_{8} \mathrm{O}_{7}$ & 25 & 105 & 0.010 & 0.014 \\
$\mathrm{CH}_{3} \mathrm{COOH}$ & 98 & 105 & 0.011 & 0.010 \\
$\mathrm{HCOOH}$ & 98 & 105 & 0.048 & 0.050 \\
$\mathrm{NaOH}$ & 40 & 105 & 0.150 & 0.040 \\
\hline
\end{tabular}

morphology that corrosion occurs mainly in grain boundaries of alumina ceramic materials $\left(\mathrm{Al}_{2} \mathrm{O}_{3}\right)$ Fig. 1 [20] and that mass loss increases with increasing temperature (Fig. 2) [20].

Interaction between $\mathrm{CaO}-\mathrm{Al}_{2} \mathrm{O}_{3}-\mathrm{SiO}_{2}$ leads to the formation of phases with low melting point temperatures, such as gehlenite or anorthite. Nanomaterials in shaped refractories raise the surface energy making them more reactive. Thus, their resistance to corrosion and thermal shock can be improved if the interaction of nano-phases with the other particles is favorably adapted [12].

Maitra, Das and Sen [12] studied the effect of tiny titanium oxide particles on densification of molten refractory cement $\mathrm{Al}_{2} \mathrm{O}_{3}-\mathrm{MgO}$. They observed that the addition of $\mathrm{TiO}_{2}$ results in a positive influence in densification, spinel formation and reduction in grain sizes of spinel formed at high temperatures in this system, modifying physical properties such as contraction in cooking, apparent density, apparent porosity and actual density. Besides, the microstructure of the bodies with added $\mathrm{TiO}_{2}$ became more uniform and with less content of vitreous phases. Thus, it was suggested that the addition of $\mathrm{TiO}_{2}$ leads to densification and phase formation, having a direct influence in the increase in their properties [12].

Takehiko Hirataet al. [1] reported that corrosion depth in $\mathrm{Al}_{2} \mathrm{O}_{3}$ ceramics is reduced by adding $\mathrm{Cr}_{2} \mathrm{O}_{3}$, reaching the lowest corrosión value with $81.6 \% \mathrm{Cr}_{2} \mathrm{O}_{3}$ mol- $14.4 \mathrm{~mol} \%$ $\mathrm{Al}_{2} \mathrm{O}_{3}-4 \mathrm{~mol}$ TiO in the mixture. This is caused by diffusion difference in $\mathrm{Cr}_{2} \mathrm{O}_{3}$, because diffusion rate for the $\mathrm{Cr}$ ion is rather slow compared to other metal ions (Fig. 3). It was also reported that corrosion depth increased by increasing $\mathrm{CaO}$ ratio contained in the slag, on the ceramic matrix formed by $\mathrm{CrO}_{2}-\mathrm{Al}_{2} \mathrm{O}_{3}$ (Fig. 3) [1]. Since solubility and viscosity properties change in the slag as $\mathrm{CaO}$ content 
Table 4 Acid and alkalis resistance of ceramics and porcelain [2]

\begin{tabular}{|c|c|c|c|c|c|c|}
\hline \multirow[t]{4}{*}{ Parameter } & \multicolumn{6}{|c|}{ Chemical resistance of porcelain mixtures containing oxides \% } \\
\hline & \multicolumn{2}{|l|}{ No.1 } & \multicolumn{2}{|l|}{ No.2 } & \multicolumn{2}{|l|}{ No.3 } \\
\hline & $\mathrm{SiO}_{2}$ & $\mathrm{Al}_{2} \mathrm{O}_{3}$ & $\mathrm{SiO}_{2}$ & $\mathrm{Al}_{2} \mathrm{O}_{3}$ & $\mathrm{SiO}_{2}$ & $\mathrm{Al}_{2} \mathrm{O}_{3}$ \\
\hline & 67.00 & 23.00 & 56.60 & 38.32 & 25.00 & 71.00 \\
\hline Resistance acid & 98.3 & & 98.72 & & 98.94 & \\
\hline Resistance alkaline & 58.12 & & 72.19 & & 88.59 & \\
\hline
\end{tabular}

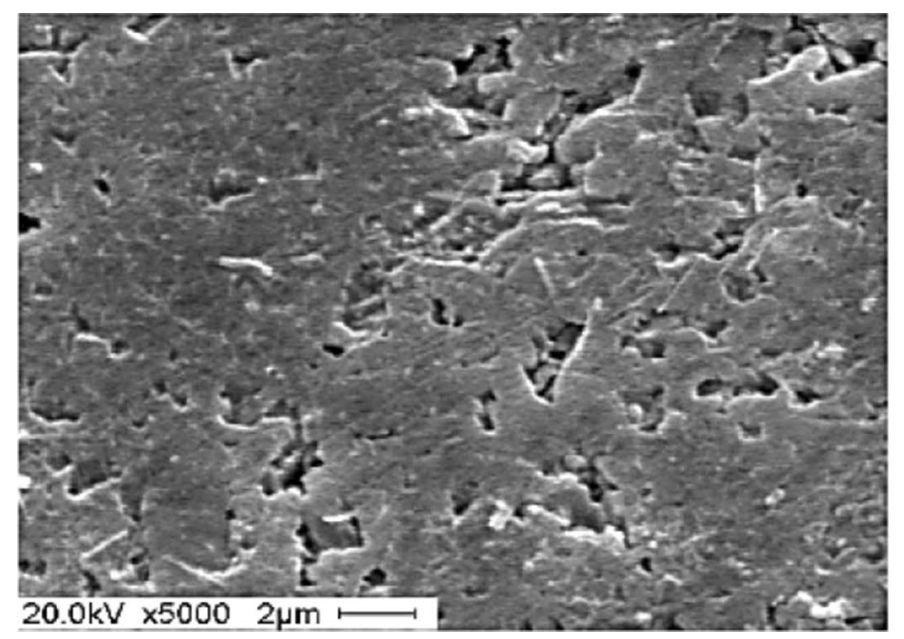

Fig. 1 SEM image of $\mathrm{Al}_{2} \mathrm{O}_{3}$ before and after $\mathrm{NaOH}$ corrosion [20]

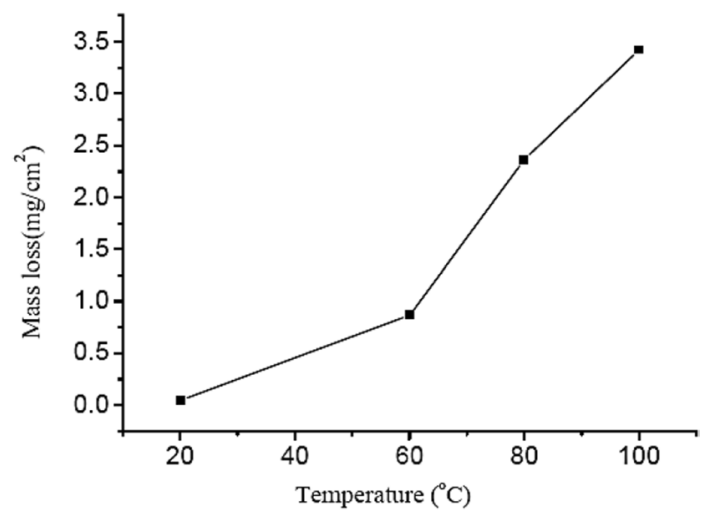

Fig. 2 Mass loss of $\mathrm{Al}_{2} \mathrm{O}_{3}$ with different solution temperatures $(0.5 \mathrm{M} \mathrm{NaOH})$, exposed for $5 \mathrm{~h}[20]$

changes [21]. The dissolution process in ceramics can be controlled by the diffusion of oxide components, through the limiting layer of slag existing in the front side of the oxide surface, or by dissolution rate of oxides in the slag [1].

Liu et al. [18] studied corrosion resistance by adding $\mathrm{ZrO}_{2}$ to a refractory $\mathrm{Al}_{2} \mathrm{O}_{3}-\mathrm{C}$. Pointing that, adding $\mathrm{ZrO}_{2}$ ion gives anticorrosive characteristics to $\mathrm{Al}_{2} \mathrm{O}_{3}-\mathrm{C}$ base, especially in $\mathrm{FeO}$ castings with concentrations higher than $6 \%$, where carbon graphite $\mathrm{Al}_{2} \mathrm{O}_{3}-\mathrm{C}$ content is converted

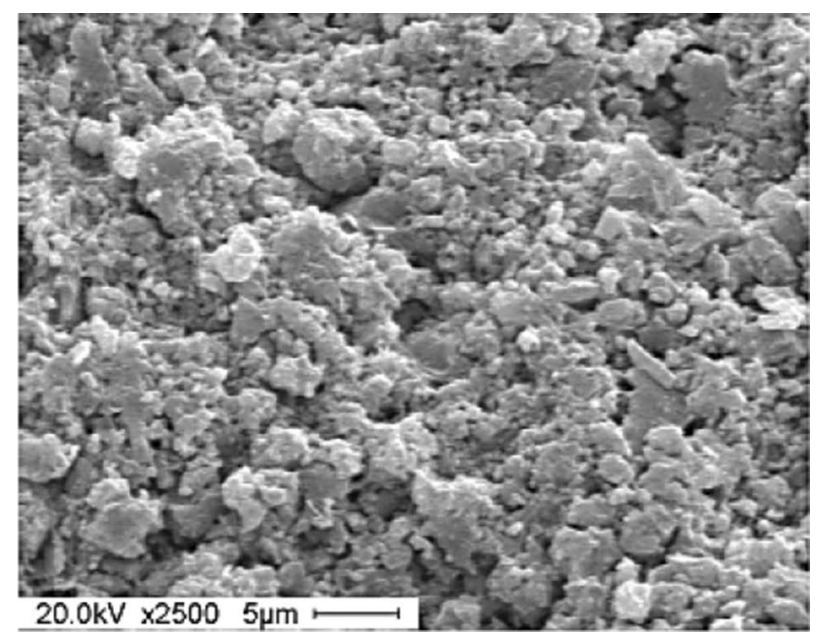

in reducing agent of iron oxide, which is present in the casting. Figure 4 shows the relationship between $\mathrm{FeO}$ iron concentration and degree of corrosion [18].

$M$ Serhat and Kara [3] reported that the addition of zirconia $\mathrm{ZrSiO}_{4}$ to the mullite sintered matrix $3 \mathrm{Al}_{2} \mathrm{O}_{3} 2 \mathrm{SiO}_{2}$ improves mechanical and corrosive properties upon alkaline vapors $\left(\mathrm{Na}_{2} \mathrm{O}\right)$. Even considering that alkaline vapor corrosion is very severe for alumina-silicate refractories, since new phases produce stress and cracking. This is because of densification in mullite by adding zirconia to the mixture. Densification in the mixture reduces infiltration of alkaline vapors with reduction in porosity in the refractory material. Thus, when zirconia is added to the alumina-silica $\mathrm{SiO}_{2}$ mixture (Fig. 5), it is possible to reduce apparent porosity to $8.9 \%$ increasing its corrosion resistance to alkaline vapors [3]. Porosity depends on the distribution of grain size for the sintered mixture. A structural ceramic material should have a porosity $<2 \%$, whereas for a refractory it should be above $20 \%$ and between 50 and 70\% for refractory insulation [22].

An EDX analysis in the densified area shows that the chemical composition at the reaction zone is different from that of the green material, where atoms of sodium, aluminum, silicon and oxygen were found in the reaction areas, and sodium was not found in the affected part [3]. 

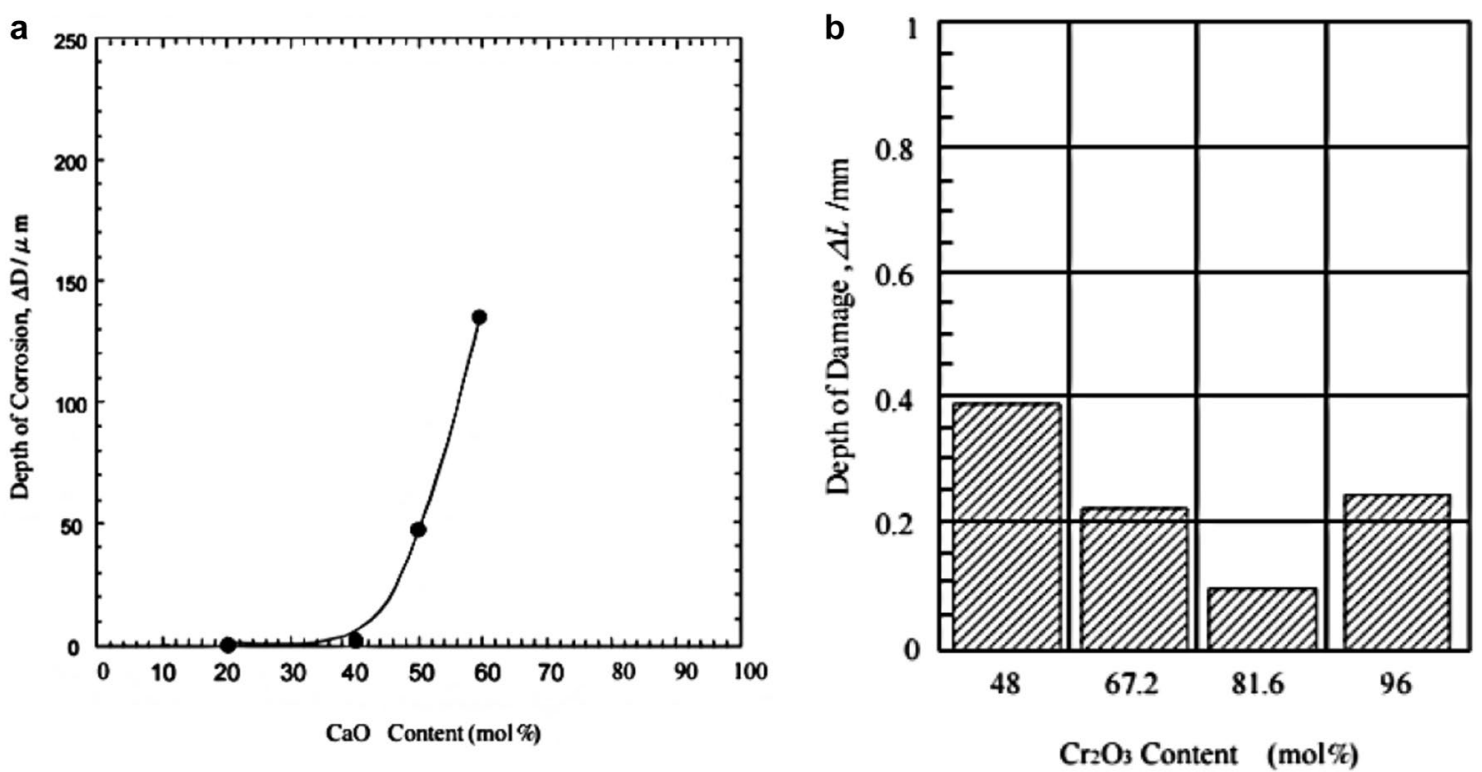

Fig. 3 a The relationship between the depth of corrosion and $\mathrm{CaO}$ content in the $\mathrm{CaO}-\mathrm{SiO}_{2}-\mathrm{Al}_{2} \mathrm{O}_{3}$-based molten oxide. $\mathbf{b}$ Content of $\mathrm{CaO}$ [1]

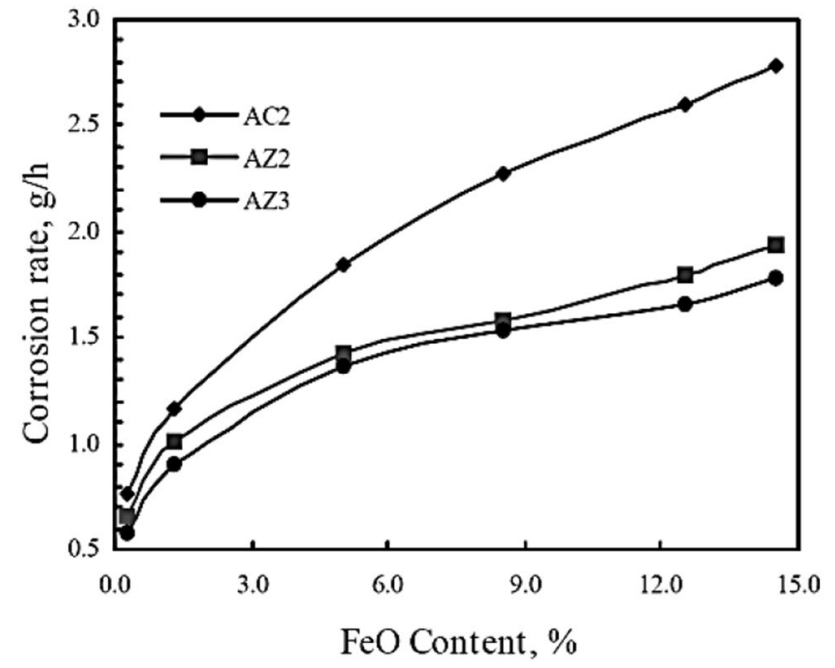

Fig. 4 FeO content in melts and the corrosion rate of the refractories, test temperature $1773^{\circ} \mathrm{K}$. [18]

LidijaĆurković et al. [4] determined the correlation between the number of ions eluted from $\mathrm{Al}_{2} \mathrm{O}_{3}$ ceramics and time of immersion at different concentrations of $\mathrm{H}_{2} \mathrm{SO}_{4}$. This ratio shows the number of ions dissolved after corrosion process containing ions of de $\mathrm{Al}^{3+}, \mathrm{Mg}^{2+}$, $\mathrm{Ca}^{2+}, \mathrm{Na}^{+}, \mathrm{Si}^{4+}$ and $\mathrm{Fe}^{3+}$. This shows that impurities play an important role in corrosion process of ceramic alumina, since corrosion degree in $\mathrm{Al}^{3+}, \mathrm{Mg}^{2+}, \mathrm{Ca}^{2+}, \mathrm{Na}^{+}, \mathrm{Si}^{4+}$ and $\mathrm{Fe}^{3+}$ increases with corrosion time. Kinetic corrosion of high-purity $\mathrm{Al}_{2} \mathrm{O}_{3}$ ceramics at different concentrations (2, 10 and $20 \%$ ) of $\mathrm{H}_{2} \mathrm{SO}_{4}$ at room temperature showed high ion separation within the first $24 \mathrm{~h}$, and for prolonged periods above $250 \mathrm{~h}$, the effect remains stable Figure 6 [4]. Chang Woo Lee, Kang, Chang and Hahm [23] performed similar work for a porous alumina membrane subjected to $\mathrm{HCl}, \mathrm{HNO}_{3}, \mathrm{H}_{2} \mathrm{SO}_{4}$ acid solutions and $\mathrm{NaOH}, \mathrm{Ca}(\mathrm{OH})_{2}$ alkaline solutions independently highlighting the influence of temperature raise $\left(20,30\right.$ and $\left.40^{\circ} \mathrm{C}\right)$, concentration $(0.001$, $0.01,0.1 \mathrm{~N}$ ) and exposure time (30-180 $\mathrm{min}$ ) in these solutions [23].

In 1981, Irwin and Amónof Westinghouse Electric Corporation [19] identified structural materials from an acid vaporizer to assess corrosion compatibility with the process stream. They subjected ceramic materials to sulfuric acid $\left(\mathrm{H}_{2} \mathrm{SO}_{4}\right)$, under temperatures of $361-452^{\circ} \mathrm{C}$, and increments of $250-1000 \mathrm{~h}$. It was found that silicon and materials containing significant amounts of silicon, such as silicon carbide and silicon nitride, had the highest resistance to boiling sulfuric acid. In another corrosion study carried out by Fernanda Coen-Porisini [19], ceramic samples were subjected to $800^{\circ} \mathrm{C}$ in two different vapors containing certain decomposition products of sulfuric acid. Both tests did not show significant changes for $\mathrm{Al}_{2} \mathrm{O}_{3}$ alumina, $3 \mathrm{Al}_{2} \mathrm{O}_{3}$ $2 \mathrm{SiO}_{2}$ mullite, and $\mathrm{ZrSiO}_{4}$ zirconia, only small deposits on the surface. Tiegs [19] identified silicon carbide as the best ceramic exposed to temperatures between 1000 and $1225^{\circ} \mathrm{C}$ in sulfuric acid, simulating a decomposition environment. In 2004, Shintaro Ishiyama [19] applied for a patent of a high-temperature corrosion resistant ceramic; his results show a percentage change in weight and corrosion rate for the samples after $100 \mathrm{~h}$ of exposure to boiling sulfuric acid under high pressure. Based on these studies, 
Fig. 5 Outer surface of the test cups after alkali attack test [3]
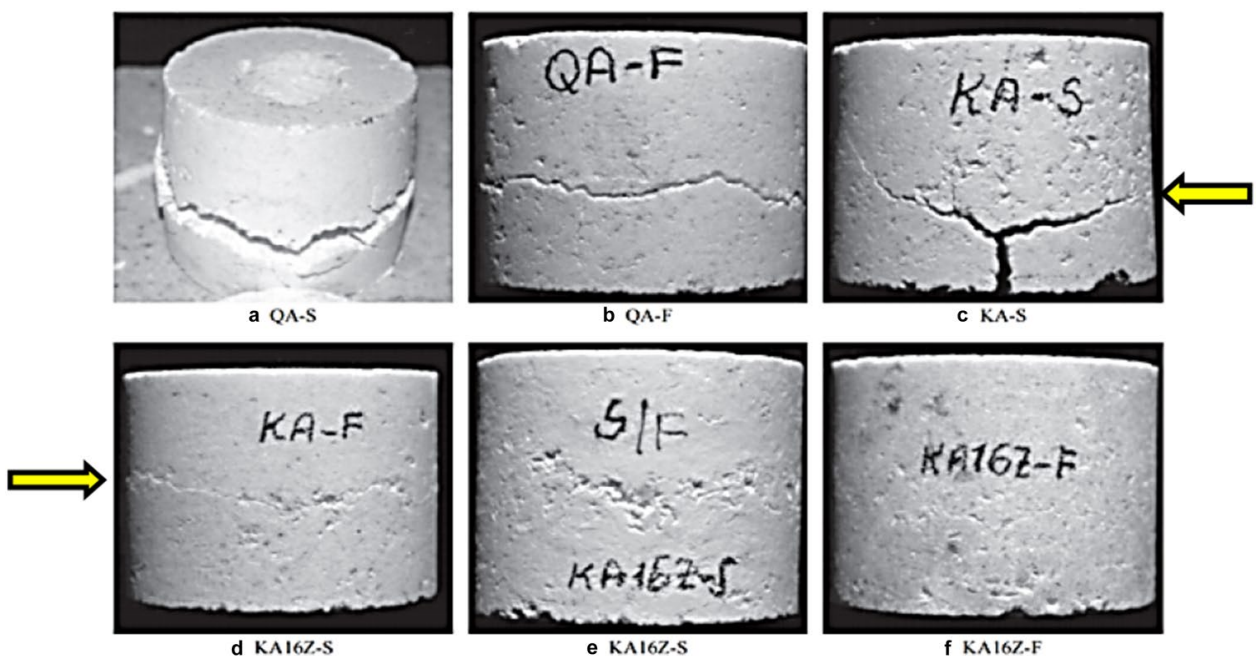

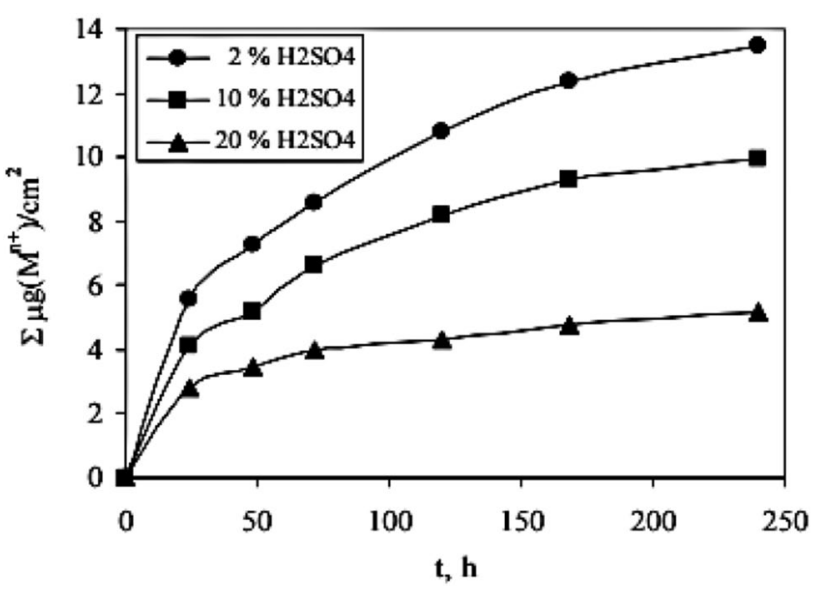

Fig. 6 Total amount of eluted ions $\left(\mathrm{Al}^{3+}, \mathrm{Mg}^{2+}, \mathrm{Ca}^{2+}, \mathrm{Na}^{+}, \mathrm{Si}^{4+}\right.$ and $\mathrm{Fe}^{3+}$ )from $\mathrm{Al}_{2} \mathrm{O}_{3}$ ceramics in different concentrations of $\mathrm{H}_{2} \mathrm{SO}_{4}$ solution [4]

we can say that $\mathrm{SiC}$ silicon carbide, $\mathrm{Si}_{3} \mathrm{~N}_{4}$ silicon nitride and $\mathrm{Al}_{2} \mathrm{O}_{3}$ alumina are the most suitable to withstand corrosion testing [19].

\section{Conclusions}

The corrosion resistance of high-purity alumina ceramics immersed in acid solutions $\left(\mathrm{H}_{2} \mathrm{SO}_{4}, \mathrm{HCl}, \mathrm{HNO}_{3}\right)$ and alkaline solutions $\left(\mathrm{NaOH}, \mathrm{KOH}, \mathrm{Na}_{2} \mathrm{O}, \mathrm{Ca}(\mathrm{OH})_{2}\right)$ is determined by the degree of solubility of impurities contained within the grain limits ( $\mathrm{MgO}, \mathrm{CaO}, \mathrm{SiO}, \mathrm{FeO}$ and $\mathrm{Na}_{2} \mathrm{O}$ ). Due to the corrosion mechanism produced is a type of intergranular corrosion with preferential attack at the grain boundaries, where most of its impurities are found.

Also concentration of acid or alkaline solutions and the exposure temperature of either acid ceramic $\left(\mathrm{SiO}_{2}\right.$,
$\mathrm{Al}_{2} \mathrm{O}_{3}$ ) or alkaline ceramics ( $\mathrm{MgO}, \mathrm{CaO}, \mathrm{Cr}_{2} \mathrm{O}_{3}$ ) are important factors to determine the corrosion resistance.

The addition of zirconium dioxide $\left(\mathrm{ZrO}_{2}\right)$, zirconium silicate $\left(\mathrm{ZrSiO}_{4}\right)$, titanium oxide $\left(\mathrm{TiO}_{2}\right)$, chromium oxide $\left(\mathrm{Cr}_{2} \mathrm{O}_{3}\right)$, or even micro-silica $\left(\mathrm{SiO}_{2}\right)$, to alumina ceramics, improves corrosion resistance, even more than by only exposing high-purity alumina ceramics to acidic or alkaline solutions. Due to this, sintering has structure such as $\mathrm{Al}_{2} \mathrm{O}_{3}-\mathrm{MgO}$ refractory cement with higher densification and reduction in grain size than spinel phase alumina $\left(\mathrm{Al}_{2} \mathrm{O}_{3}\right)$. The high produced densification causes less infiltration of corrosive medium due to low porosity. Depth corrosion is even reduced by adding amounts of $\mathrm{Cr}_{2} \mathrm{O}_{3}-\mathrm{Al}_{2} \mathrm{O}_{3}$ ceramics, because of delayed speed with which the slag diffuses through the material.

The phases that offer greater resistance to acid or alkaline solutions are achieved by sintering the alumina base ceramic material trying to obtain the higher content of corundum a- $\mathrm{Al}_{2} \mathrm{O}_{3}$ or mullite $3 \mathrm{Al}_{2} \mathrm{O}_{3} 2 \mathrm{SiO}_{2}$ phases.

Acknowledgements Authors are greatly grateful to the Universidad Autónoma de Baja California and CINVESTAV-Saltillo for facilitating access and use of their facilities and equipment to carry out this research.

\section{Compliance with ethical standards}

Conflict of interest The authors declare that they have no conflict of interest.

\section{References}

1. Hirata T, Morimoto T, Deguchi A, Uchida N (2002) Corrosion resistance of alumina-chromia ceramic materials against molten slag. Mater Trans 43(10):2561-2567

\section{SN Applied Sciences}


2. Krasnyi BL, Tarasovskii VP, Rakhmanova EV, Bondar VV (2004) Chemical resistance of ceramic materials in acids and alkalis. Glas Ceram (Engl Transl Steklo i Keram) 61(9-10):337-339

3. Başpinar MS, Kara F (2009) Optimization of the corrosion behavior of mullite refractories against alkali vapor via $\mathrm{ZrSiO}_{4}$ addition to the binder phase. Ceram -Silik 53(4):242-249

4. Curković L, Fudurić M, Kurajica S (2015) Kinetic study of the corrosion of alumina ceramics in sulphuric acid aqueous solution

5. Nickel K, Seipel B (2004) Corrosion penetration monitoring of advanced ceramics in hot aqueous fluids. Mater Res 7(1):125-133

6. Campos M, Sicre-Artalejo JA, Torralba JM, Zbiral H, Danninger H, Pena P (2014) Degradation of alumina refractory bricks by sintering Mn low-alloy steels. Ceram Int 40(2):3063-3070

7. Mahnicka $L$ (2012) Influence of raw materials ratio and sintering temperature on the properties of the refractory mullite-corundum ceramics. Waset 6(3):404-409

8. Duval DJ, Risbud SH, Shackelford JF (2008) Ceramic and glass materials: structure, properties and processing, 1st edn. Springer US, Boston, MA

9. Biscaye PE (1965) Mineralogy and sedimentation of recent deepsea clay in the atlantic ocean and adjacent seas and oceans. Geol Soc Am Bull 76(7):803

10. He L, Liu Q (1997) Chemical characteristics of clay minerals in the sediments from the Yellow River and the Changjiang River. Chin Sci Bull 42(6):488-492

11. Kabeto K, Zenebe A, Bheemalingeswara K, Atshbeha K, Gebresilassie S, Amare K (2012) Mineralogical and geochemical characterization of clay and lacustrine deposits of lake Ashenge Basin, northern Ethiopia: implication for industrial applications. Momona Ethiop J Sci 4(2):111-129

12. Badiee SH, Otroj S (2011) The effect of nano-titania addition on the properties of high-alumina low-cement self-flowing refractory castables. Ceram. -Silik 55(4):319-325

13. Chen SS-K, Cheng MM-Y, Lin SS-J, Ko Y-CY (2002) Thermal characteristics of $\mathrm{Al}_{2} \mathrm{O}_{3}-\mathrm{MgO}$ and $\mathrm{Al}_{2} \mathrm{O}_{3}$ - spinel castables for steel ladles. Ceram Int 28(7):811-817
14. Rohan P, Neufuss K, Matějíček J, Dubský J, Prchlík L, Holzgartner $C$ (2004) Thermal and mechanical properties of cordierite, mullite and steatite produced by plasma spraying. Ceram Int 30(4):597-603

15. Kirsever D, Karakus N, Toplan N, Toplan HO (2015) The cordierite formation in mechanically activated Talc-Kaoline-Alumina-Basalt-Quartz ceramic system. Acta Phys Pol A 127(4):1042-1044

16. Koli DK (2013) Properties and characterization of $\mathrm{Al}-\mathrm{Al}_{2} \mathrm{O}_{3} \mathrm{com}$ posites processed by casting and powder metallurgy routes (review). Composites 2(4):486-496

17. Garcia FG, Rodriguez MG, Vilchez CG, Pichardo MR (1992) Efectos de la molienda seca sobre un material natural que contienen pirofilita y caolinita. Bol Soc Esp Ceram Vidr 31(7):297-304

18. Liu WGQ, Zheng H, Lu C (2008) Corrosion resistance of highalumina graphite based refractories to the smelting reduction melts. J Mater Sci Eng 2(12):49-53

19. Wright EN, Wilson MA, Lewinsohn CA (2006) Corrosion performance of ceramic materials in high temperature sulfuric acid environments. AIChE Annual Meeting November, no. 14, pp 1-5. https://pdfs.semanticscholar.org/1075/a551b46055508d503d3a $5819 \mathrm{~d} 2 \mathrm{c} 83 \mathrm{fd} 29 \mathrm{cf} 0 . \mathrm{pdf}$

20. Huang $\mathrm{L}$, Luo S, LiW (2012) Corrosion behavior of $\mathrm{Al}_{2} \mathrm{O}_{3}$ ceramics in the acid and alkaline solutions. Key Eng Mater 515:509-512

21. Oliveira FA, Miller A, Madías J (1999) Tensión superficial, viscosidad y densidad de algunas escorias $\mathrm{CaO}-\mathrm{Al}_{2} \mathrm{O}_{3}$. Rev Metal 35(2):91-99

22. Sastri VS, Ghali E, Elboujdaini M (2007) Corrosion prevention and protection: practical solutions, 1st edn. Wiley. https://onlinelibr ary.wiley.com/doi/book/10.1002/9780470024546

23. Lee $C$, Kang H, Chang Y, Hahm Y (2000) Thermotreatment and chemical resistance of porous alumina membrane prepared by anodic oxidation. Korean J Chem Eng 17(3):266-272

Publisher's Note Springer Nature remains neutral with regard to jurisdictional claims in published maps and institutional affiliations. 